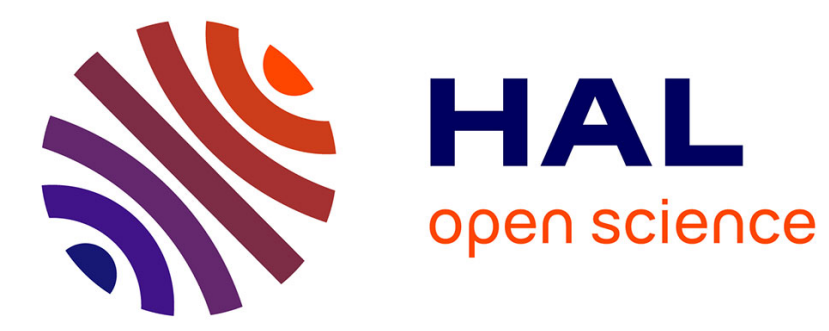

\title{
The Insulinotropic Effect of Fluoroquinolones
}

Hani Ghaly, Christine Kriete, Seher Sahin, Anja Pflöger, Ulrike Holzgrabe, Bernd Joachim Zünkler, Ingo Rustenbeck

\section{To cite this version:}

Hani Ghaly, Christine Kriete, Seher Sahin, Anja Pflöger, Ulrike Holzgrabe, et al.. The Insulinotropic Effect of Fluoroquinolones. Biochemical Pharmacology, 2009, 77 (6), pp.1040. 10.1016/j.bcp.2008.11.019 . hal-00531843

\section{HAL Id: hal-00531843 https://hal.science/hal-00531843}

Submitted on 4 Nov 2010

HAL is a multi-disciplinary open access archive for the deposit and dissemination of scientific research documents, whether they are published or not. The documents may come from teaching and research institutions in France or abroad, or from public or private research centers.
L'archive ouverte pluridisciplinaire HAL, est destinée au dépôt et à la diffusion de documents scientifiques de niveau recherche, publiés ou non, émanant des établissements d'enseignement et de recherche français ou étrangers, des laboratoires publics ou privés. 


\section{Accepted Manuscript}

Title: The Insulinotropic Effect of Fluoroquinolones

Authors: Hani Ghaly, Christine Kriete, Seher Sahin, Anja Pflöger, Ulrike Holzgrabe, Bernd Joachim Zünkler, Ingo

Rustenbeck

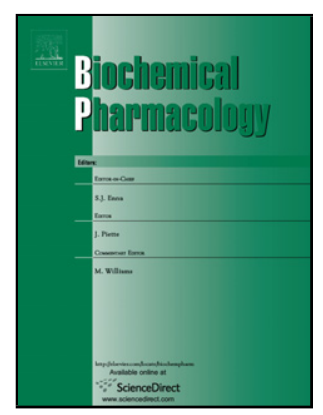

PII:

S0006-2952(08)00854-X

DOI: doi:10.1016/j.bcp.2008.11.019

Reference: BCP 10023

To appear in: $B C P$

Received date: 19-9-2008

Revised date: 19-11-2008

Accepted date: $19-11-2008$

Please cite this article as: Ghaly H, Kriete C, Sahin S, Pflöger A, Holzgrabe U, Zünkler BJ, Rustenbeck I, The Insulinotropic Effect of Fluoroquinolones, Biochemical Pharmacology (2008), doi:10.1016/j.bcp.2008.11.019

This is a PDF file of an unedited manuscript that has been accepted for publication. As a service to our customers we are providing this early version of the manuscript. The manuscript will undergo copyediting, typesetting, and review of the resulting proof before it is published in its final form. Please note that during the production process errors may be discovered which could affect the content, and all legal disclaimers that apply to the journal pertain. 
The Insulinotropic Effect of Fluoroquinolones

17.11 .08

Hani Ghaly ${ }^{1 \mathrm{a}}$, Christine Kriete ${ }^{1 \mathrm{a}}$, Seher Sahin ${ }^{1}$, Anja Pflöger ${ }^{1}$ Ulrike Holzgrabe ${ }^{2}$, Bernd Joachim Zünkler ${ }^{3}$, Ingo Rustenbeck ${ }^{1} *$

${ }^{1}$ Institute of Pharmacology and Toxicology, University of Braunschweig, D-38106

Braunschweig, Germany, ${ }^{2}$ Institute of Pharmaceutical Chemistry, University of Würzburg, D-

97074 Würzburg, ${ }^{3}$ Federal Institute for Drugs and Medical Devices, D-53175 Bonn, Germany

athese authors contributed equally to this paper

*Corresponding author. Fax: +49/531/3918287; E-mail address: i.rustenbeck@tu-bs.de 


\begin{abstract}
Antimicrobial fluoroquinolones induce, with strongly varying frequency, life-threatening hypoglycemias, which is explained by their ability to block $\mathrm{K}_{\mathrm{ATP}}$ channels in pancreatic $\mathrm{B}$ cells and thus to initiate insulin secretion. In apparent contradiction to this, we observed that none of the fluoroquinolones in this study (gatifloxacin, moxifloxacin, ciprofloxacin, and a number of fluorophenyl-substituted compounds) initiated insulin secretion of perifused mouse islets when the glucose concentration was basal ( $5 \mathrm{mM})$. Only when the glucose concentration was stimulatory by itself $(10 \mathrm{mM})$, the fluoroquinolones enhanced secretion. The fluoroquinolones were ineffective on SUR1 Ko islets, which do not have functional $\mathrm{K}_{\mathrm{ATP}}$ channels. All of these fluoroquinolones depolarized the membrane potential of mouse B-cells (patch-clamping in the whole-cell mode). Using metabolically intact B-cells (perforated-patch mode) however, $100 \mu \mathrm{M}$ of gatifloxacin, ciprofloxacin or moxifloxacin were unable to depolarize when the glucose concentration was $5 \mathrm{mM}$, whereas other $\mathrm{K}_{\mathrm{ATP}}$ channel blockers (tolbutamide and efaroxan) remained effective. Only at a very high concentration $(500 \mu \mathrm{M})$ gatifloxacin and moxifloxacin, but not ciprofloxacin induced repetitive depolarizations which could be antagonized by diazoxide. In the presence of $10 \mathrm{mM}$ glucose all fluoroquinolones which enhanced secretion markedly elevated cytosolic calcium concentration $\left(\left[\mathrm{Ca}^{2+}\right]_{\mathrm{i}}\right)$. In the presence of $5 \mathrm{mM}$ glucose gatifloxacin and moxifloxacin at $500 \mu \mathrm{M}$ but not at $100 \mu \mathrm{M}$ elevated $\left[\mathrm{Ca}^{2+}\right]_{\mathrm{i}}$. It is concluded that fluoroquinolones in the clinically relevant concentration range are not initiators, but rather enhancers of glucose-induced insulin secretion. The block of $\mathrm{K}_{\mathrm{ATP}}$ channels appears necessary but not sufficient to explain the hypoglycemic effect of fluoroquinolones.
\end{abstract}

$252 \mathrm{w}$

Keywords: Fluoroquinolones; Gatifloxacin; $\mathrm{K}_{\mathrm{ATP}}$ channel; Plasma membrane potential; Cytosolic calcium concentration; Insulin secretion

Abbreviations: $\left[\mathrm{Ca}^{2+}\right]_{\mathrm{i}}$ : cytosolic free calcium concentration; $\mathrm{K}_{\mathrm{ATP}}$ channel, ATP-sensitive $\mathrm{K}^{+}$ channel; SUR: sulfonylurea receptor 


\section{Introduction}

Disturbances in glucose homeostasis are increasingly recognized as one of the most relevant adverse effects of antibacterial fluoroquinolones. Both, hypoglycemic and hyperglycemic episodes occur during therapy [1,2]. Hypoglycemias are rare, however, they are potentially life-threatening and have led to a number of fatalities [2]. While some of the hypoglycemic episodes have to be attributed to an interaction with sulfonylurea antidiabetic drugs [3-5], it is generally accepted that fluoroquinolones by themselves can induce hypoglycemias and concomitant sulfonylurea therapy is an independent risk factor [6].

The characterization of a direct insulinotropic effect of fluoroquinolones on isolated rat pancreatic islets led to the hypothesis that a block of $\mathrm{B}$-cell $\mathrm{K}_{\mathrm{ATP}}$ channels was responsible for this effect [7]. It is generally agreed that the pharmacological closure of $\mathrm{K}_{\mathrm{ATP}}$ channels leads to a depolarization of the B-cell plasma membrane and influx of calcium via voltagedependent calcium channels, which in turn activates the exocytotic machinery [8]. However, the secretion elicited by the increase in the cytosolic free calcium concentration $\left(\left[\mathrm{Ca}^{2+}\right]_{i}\right)$ remains modest if there is no concomitant increase in energy metabolism as is produced by glucose, the main physiological stimulus. By as yet unidentified signals the glucose metabolism of the B-cell strongly amplifies the secretion initiated by the $\mathrm{Ca}^{2+}$ signal. Thus, the stimulus secretion coupling in pancreatic B-cells can be viewed as a bifurcating pathway, one branch being $\mathrm{K}_{\mathrm{ATP}}$ channel-dependent, the other $\mathrm{K}_{\mathrm{ATP}}$ channel-independent. These branches are also referred to as triggering and amplifying pathways, respectively [9].

It could be shown that two fluoroquinolones, lomefloxacin and norfloxacin, inhibited $\mathrm{K}_{\mathrm{ATP}}$ channel activity in insulin-secreting RINm5F cells [10]. Following the above outlined view on stimulus-secretion coupling in B-cells, the fluoroquinolones should thus be able to initiate insulin secretion. The $\mathrm{K}_{\mathrm{ATP}}$ channel block was due to a direct effect at the poreforming subunit Kir6.2 [11], whereas sulfonylureas, the classical blockers of $\mathrm{K}_{\mathrm{ATP}}$ channels, which are used as oral antidiabetic drugs, act via binding to the regulatory subunit SUR1 [12]. The observation that gatifloxacin and temafloxacin, which were more potent than levofloxacin to block the $\mathrm{K}_{\mathrm{ATP}}$ channel were also more effective to increase the insulin release from statically incubated mouse islets [11] further supported the hypothesis that block of this channel is responsible for the hypoglycemias.

However, there are inconsistencies. While case reports of hypoglycemias exist for a number of fluoroquinolones, pharmacoepidemiologic evidence clearly documents an outstanding role of gatifloxacin as an inducer of hypoglycemias [1,2]. Since in one large trial the risk of other fluoroquinolones was found not to be different from that of other antibacterial drugs it has been supposed that the induction of glucose abnormalities is not a class effect of fluoroquinolones [1]. Also, the fluoroquinolones norfloxacin and levofloxacin were found to be only weakly effective as $\mathrm{K}_{\mathrm{ATP}}$ channel blockers [10,11], but nevertheless there are case reports linking these compounds to severe and even lethal hypogycemias [13, 14], which 
raises the question as to whether there are unidentified triggering factors. Finally, gatifloxacin is also associated with the induction of hyperglycemic episodes in diabetic and non-diabetic patients $[15,16]$. The hyperglycemic episodes, which are even more frequent than the hypoglycemic episodes [1] are not easily explained by a block of $\mathrm{K}_{\mathrm{ATP}}$ channels [17].

By studying the insulinotropic effects of an array of fluoroquinolones comprizing clinically relevant and structurally systematically varied compounds (Fig. 1) and by comparing these effects with those on membrane potential and $\left[\mathrm{Ca}^{2+}\right]_{i}$ we sought to answer the following questions: i) Is the stimulation of insulin secretion a group effect of fluoroquinolones? ii) Is the insulinotropic effect dependent on the block of $\mathrm{K}_{\mathrm{ATP}}$ channels or are $\mathrm{K}_{\mathrm{ATP}}$ channelindependent mechanisms involved? iii) Can structural features be identified which confer the insulinotropic effect?

\section{Materials and methods}

\subsection{Chemicals}

Gatifloxacin was kindly provided by Grünenthal (Aachen, Germany), ciprofloxacin and moxifloxacin were bought as solutions for i.v. use. The N1-aryl fluoroquinolones (1-(4fluorophenyl)-6-fluor-1,4-dihydro-4-oxo-7-(2,6-dimethylpiperazine-4-yl)-3-quinolinecarbonic acid $=\mathrm{C} 1$; 1-(2-fluorophenyl)-6-fluor-1,4-dihydro-4-oxo-7-(2,6-dimethylpiperazine-4-yl)-3quinolinecarbonic acid = C2; 1-(4-fluorophenyl)-6-fluor-1,4-dihydro-4-oxo-7-(piperazine-4yl)-3-quinolinecarbonic acid = C3; (1-(2-fluorophenyl)-6-fluor-1,4-dihydro-4-oxo-7(piperazine-4-yl)-3-quinolinecarbonic acid = C4) were synthesized as described earlier [18]. Lomefloxacin, norfloxacin and diazoxide were obtained from Sigma (Taufkirchen, Germany), tolbutamide from Serva (Heidelberg, Germany), efaroxan from Tocris (Bristol, UK), and D600 (methoxyverapamil) from Knoll (Ludwigshafen, Germany). Collagenase P for pancreatic islet isolation was supplied by Roche Diagnostics (Mannheim, Germany), Fura2/AM by Molecular Probes (Leiden, The Netherlands), cell culture medium RPMI 1640 by was from Gibco/Invitrogen (Karlsruhe, Germany) and fetal calf serum from PAA (Cölbe, Germany). All other reagents of analytical grade were from E. Merck (Darmstadt, Germany). Tolbutamide stock solutions were prepared in $0.1 \mathrm{~N} \mathrm{NaOH}$.

\subsection{Tissue}

Islets were isolated from the pancreas of NMRI mice or SUR1 Ko mice (12 - 16 weeks old, fed ad libitum) by a collagenase digestion technique and hand-picked under a stereomicroscope. Single cells were obtained by incubation of the islets for $10 \mathrm{~min}$ in a $\mathrm{Ca}^{2+}$ free medium and subsequent vortex-mixing for $1 \mathrm{~min}$. Single islet cells were cultured on glass cover slips for up to 4 days in cell culture medium RPMI-1640 with $10 \%$ fetal calf serum (5 $\mathrm{mM}$ glucose) in a humidified atmosphere of $95 \%$ air and $5 \% \mathrm{CO}_{2}$ at $37^{\circ} \mathrm{C}$.

\subsection{Measurement of insulin secretion.}


Batches of 50 freshly isolated NMRI mouse islets were introduced into a purposemade perifusion chamber thermostatically controlled at $37{ }^{\circ} \mathrm{C}$ and perifused $(1 \mathrm{ml} / \mathrm{min})$ with a HEPES-buffered Krebs-Ringer medium containing the respective secretagogues. The insulin content in the fractionated effluate was determined by ELISA (Mercodia, Uppsala, Sweden) according to the instructions of the manufacturer.

\subsection{Electrophysiological Recordings}

Pipettes were pulled from borosilicate glass ( $2 \mathrm{~mm}$ o.d., $1.4 \mathrm{~mm}$ i.d., Hilgenberg, Malsfeld, Germany) by a two-stage vertical puller (List Electronic, Darmstadt, Germany ) and had resistances between 3 and $6 \mathrm{MOhm}$ when filled with solution. Currents and voltages were recorded by an EPC 7 patch-clamp amplifier (List Electronic), and low pass-filtered by a 4pole Bessel filter at $2 \mathrm{kHz}$ and stored on a video tape. The membrane potential of B-cells was determined using the whole-cell and perforated patch modes under current clamp condition. The patch perforation was achieved by $100 \mu \mathrm{g} / \mathrm{ml}$ nystatin in the pipette solution [19]. Exposure to the test compounds and and wash-out was done by a slow bath perfusion system. The compositions of the bath and pipette media were as given by Zünkler et al. [20]. The glucose concentration of the extracellular solution was $0 \mathrm{mM}$ in the whole cell mode and 5 $\mathrm{mM}$ in the perforated patch mode. All experiments were performed at room temperature (20 $23^{\circ} \mathrm{C}$ ). Data were analysed off-line using pClamp 6.03 software (Axon Instruments, Foster City, CA, USA).

\subsection{Microfluorimetric Measurements of the Cytosolic $\mathrm{Ca}^{2+}$-Concentration $\left(\left[\mathrm{Ca}^{2+}\right] \mathrm{i}\right)$}

Islet cells were cultured on glass cover slips in Petri dishes and were used from day 2 to 4 after isolation. Fura-2/AM was loaded at a concentration of $2 \mu \mathrm{M}$ for $35 \mathrm{~min}$ at $37^{\circ} \mathrm{C}$. The cover slip with the attached cells was inserted in a purpose-made perifusion chamber on the stage of an epifluorescence microscope fitted with a Zeiss Fluar (40 $\mathrm{x}$ ) objective. The fluorescence (excitation at 340 or $380 \mathrm{~nm}$, emission $>470 \mathrm{~nm}$ ) was recorded by a slow-scan CCD camera (TILL Photonics). All perifusions were performed at $30 \pm 0.5^{\circ} \mathrm{C}$ using a HEPES-buffered Krebs-Ringer bicarbonate medium. Image pairs were taken at intervals as indicated in the figures. The measurements were rendered difficult by the autofluorescence of the fluoroquinolones. The fluorescence emission overlapped with the Fura emission spectrum and varied depending on the medium composition. Thus for each individual compound a correction was necessary. This was achieved by repeating each experiment with sham-loaded B-cells. The fluorescence trace excited at $340 \mathrm{~nm}$ and that excited at $380 \mathrm{~nm}$ were subtracted from the corresponding trace obtained with Fura-loaded B-cells. This way a net fluorescence ratio (Fig. 2) was obtained which was a measure of $\left[\mathrm{Ca}^{2+}\right]_{\text {. }}$.

\subsection{Data handling and statistics.}

Statistical calculations were performed by Prism and Instat software (GraphPad, San Diego CA, USA). 


\section{Results}

\subsection{Insulinotropic effect in the presence of a stimulatory glucose concentration}

Since earlier measurements of the $\mathrm{K}_{\mathrm{ATP}}$ channel activity had shown that lomefloxacin, but not norfloxacin had a considerable blocking effect [10], these two fluoroquinolones were initially selected for a comparison of the insulinotropic activity. Islets were perifused with both drugs in sequence. Lomefloxaxin elicited a 3fold increase within 15 min (Fig. 3A). After a wash-out period of $20 \mathrm{~min}$, prestimulatory secretion levels were practically re-established and $100 \mu \mathrm{M}$ norfloxacin were added to the perifusion medium. Norfloxacin proved to be devoid of an insulinotropic effect. The same was true when the islets were exposed to these fluoroquinolones in a reverse order (Fig. 3A). Since a steady state of the lomefloxacin effect was apparently not achieved after $15 \mathrm{~min}$, the drug perifusion time was prolonged to $30 \mathrm{~min}$. Here, $100 \mu \mathrm{M}$ lomefloxacin enhanced the insulin secretion 4.5fold, whereas $100 \mu \mathrm{M}$ norfloxacin had still no effect (data not shown).

In the next set of experiments the insulinotropic effect of the clinically relevant fluoroquinolones gatifloxacin, ciprofloxacin and moxifloxacin was characterized. In the presence of $10 \mathrm{mM}$ glucose $100 \mu \mathrm{M}$ gatifloxacin showed a clear enhancing effect on insulin secretion whereas the effect of ciprofloxacin and moxifloxacin was less obvious. However, after normalization of the data (Fig. 3B) a clear difference between the control perifusion and the exposure to ciprofloxacin or moxifloxacin became apparent. The insulinotropic efficacy (area under the curve for the time period 60 to $90 \mathrm{~min}$ ) increased in the order: control < ciprofloxacin $<$ moxifloxacin $<$ gatifloxacin $(\mathrm{p}<0.05$, ANOVA). The modest effect size of moxifloxacin and ciprofloxacin was apparently due to the slow kinetics of action whereas the effect of of gatifloxacin had practically reached saturation within $30 \mathrm{~min}$ of perifusion. The subsequent exposure to a strongly depolarizing $\mathrm{KCl}$ concentration resulted in each case in massive increase of insulin secretion. At $10 \mu \mathrm{M}$, gatifloxacin was marginally effective and without effect at $1 \mu \mathrm{M}$ (data not shown).

The relevance of specific substituents for the insulinotropic effect was further assessed by including a number of systematically varied N1-aryl fluoroquinolones. While compound $\mathrm{C} 2$ proved to be strongly effective in the presence of $10 \mathrm{mM}$ glucose, all other compounds of this series $(\mathrm{C} 1, \mathrm{C} 3, \mathrm{C} 4)$ had only a moderate stimulatory effect. The secretion rates produced by these weakly effective compounds were still increasing at the end of the 30 min exposure time, suggesting that a steady state had not yet been reached (Fig. 3C).

\subsection{Glucose-dependency of the insulinotropic effect}

Gatifloxacin, ciprofloxacin and moxifloxacin were used to assess the glucose dependency of the insulinotropic effect. For the first 90 minutes, the islets were perifused with Krebs-Ringer medium containing $5 \mathrm{mM}$ glucose. During the exposure to the fluoroquinolones, from $90 \mathrm{~min}$ to the end of the perifusion, the glucose concentration was increased to $10 \mathrm{mM}$. In the presence of $5 \mathrm{mM}$ glucose, all of the fluoroquinolones were 
virtually devoid of an insulinotropic effect. When the glucose concentration was increased to $10 \mathrm{mM}$ all compounds clearly enhanced the biphasic secretion elicited by the increased glucose concentration (Fig. 4A). When the data were normalized with respect to the secretion rate before exposure to the fluoroquinolones (Fig. 4B), ciprofloxacin and gatifloxacin were more effective than moxifloxacin, which was more effective than control (area under the curve for the time period 90 to $125 \mathrm{~min}, \mathrm{p}<0.05$, t-test). In the presence of $30 \mathrm{mM}$ glucose a 30 min perifusion with $100 \mu \mathrm{M}$ gatifloxacin had no significant enhancing effect, whereas a subsequent depolarization by $40 \mathrm{mM} \mathrm{KCl}$ was clearly effective (data not shown).

\subsection{Lack of a $K_{\text {ATP }}$ channel-independent insulinotropic effect}

The question whether the $\mathrm{K}_{\mathrm{ATP}}$ channel block is indispensable for the insulinotropic effect was investigated by comparing the insulin release from normal NMRI mouse with that from SUR1 Ko islets. Within 20 min $100 \mu \mathrm{M}$ lomefloxacin increased the secretion of NMRI mouse islets in the presence of $10 \mathrm{mM}$ glucose to $430 \%$. Similarly, $100 \mu \mathrm{M} \mathrm{C} 2$ increased secretion to $320 \%$ of the prestimulatory rate (Fig. 5A). However, both compounds proved to be ineffective to enhance secretion of SUR1 Ko islets (Fig. 5A). In view of the prominent role of gatifloxacin as inducer of dysglycaemias, this compound was also tested for a possible $\mathrm{K}_{\mathrm{ATP}}$ channel-independent insulinotropic effect. During the $30 \mathrm{~min}$ perifusion of NMRI islets $100 \mu \mathrm{M}$ gatifloxacin increased the secretory rate to nearly $370 \%$ (Fig. 5B). The additional presence of $300 \mu \mathrm{M}$ diazoxide did not only completely antagonize the effect of gatifloxacin, but reduced the secretory rate below prestimulatory values (Fig. 5B). Gatifloxacin did not affect insulin secretion by SUR1 Ko islets and there was no inhibitory effect of diazoxide (Fig. 5B).

\subsection{Fluoroquinolone-induced depolarization of the B-cell plasma membrane}

Typically, the increase of $\left[\mathrm{Ca}^{2+}\right]_{\mathrm{i}}$ initiating exocytosis is linked to the block of $\mathrm{K}_{\mathrm{ATP}}$ channels via the depolarization of the plasma membrane, which was initially measured by patch clamping in the conventional whole cell mode. The fluoroquinolone-induced depolarization was slow, often only apparent after a lag time. Wash-out revealed a poor reversibility. These characteristics applied to all fluoroquinolones (Fig. 6, Table 1). In contrast, depolarization by tolbutamide in the same experiments showed the typical fast onset and offset before and after exposure to the fluoroquinolones (Fig. 6C and D). However, diazoxide was nearly ineffective to antagonize the fluoroquinolone-induced depolarization (Fig. 6C).

As expected, lomefloxacin was clearly more effective than norfloxacin (Table 1). Among the clinically important compounds gatifloxacin and ciprofloxacin at $50 \mu \mathrm{M}$ were highly effective (depolarization by $28.5 \mathrm{mV}$ and $25.4 \mathrm{mV}$, respectively), but moxifloxacin depolarized only by $8.6 \mathrm{mV}$ (Table 1 ). When the concentration was increased to $100 \mu \mathrm{M}$, however, moxifloxacin decreased the membrane potential by further $11.8 \mathrm{mV}$, whereas only a modest further increase occurred with gatifloxacin and ciprofloxacin (Fig. 6A and B). 
All N1-aryl fluoroquinolones were effectively depolarizing. At $50 \mu \mathrm{M}$, compounds $\mathrm{C}$, $\mathrm{C} 2$ and $\mathrm{C} 3$ depolarized by more than $20 \mathrm{mV}$ and $\mathrm{C} 4$ depolarized by $11.8 \mathrm{mV}$ (Table 1). Increasing the concentration to $100 \mu \mathrm{M}$ resulted in a further depolarization by $16 \mathrm{mV}$ with $\mathrm{C} 1$, but only by 4 to $6 \mathrm{mV}$ with $\mathrm{C} 2, \mathrm{C} 3$, and $\mathrm{C} 4$. The rank order of efficacy at $50 \mu \mathrm{M}$ was: $\mathrm{C} 2>$ $\mathrm{C} 1=\mathrm{C} 3>>\mathrm{C} 4$ and was practically unchanged at $100 \mu \mathrm{M}(\mathrm{C} 2=\mathrm{C} 1>>\mathrm{C} 3>>\mathrm{C} 4)$.

\subsection{Fluoroquinolone-induced depolarization of intact B-cells}

The depolarizing effect of ciprofloxacin, gatifloxacin and moxifloxacin was also tested in metabolically intact B-cells, i.e. using the perforated patch configuration of the patch-clamp technique. When the bath medium contained a basal glucose concentration $(5 \mathrm{mM})$, neither gatifloxacin, nor ciprofloxacin nor moxifloxacin (all tested at $100 \mu \mathrm{M}$ ) had any significant effect on the plasma membrane potential. In the same set of experiments, the sulfonylurea tolbutamide $(500 \mu \mathrm{M})$ and the imidazoline efaroxan $(100 \mu \mathrm{M})$ markedly depolarized the Bcell membrane (Fig. 7A and B). Of note, efaroxan was effective in the presence of gatifloxacin and ciprofloxacin and diazoxide antagonized its effect (Fig. 7). Only at $500 \mu \mathrm{M}$, gatifloxacin induced a depolarization with action potential spiking (Fig. 7C). In principle, the same response was seen with $500 \mu \mathrm{M}$ moxifloxacin, although the spiking episodes were less frequent. There was no depolarization by $500 \mu \mathrm{M}$ ciprofloxacin. The depolarization by gatifloxacin and moxifloxacin could be completely antagonized by $300 \mu \mathrm{M}$ diazoxide (not shown).

\subsection{Fluoroquinolone-induced increases of $\left[\mathrm{Ca}^{2+}\right]_{i}$}

At the beginning of each experiment, the Fura-loaded and the sham -loaded islet cells were exposed to a strongly depolarizing $\mathrm{K}^{+}$concentration, which served as an internal standard to assess the magnitude of the $\left[\mathrm{Ca}^{2+}\right]_{\mathrm{i}}$ increase caused by the subsequent perifusion with the fluoroquinolones (Fig. 8). The addition of the blocker of L-type $\mathrm{Ca}^{2+}$ channels, D600, informed about the contribution of $\mathrm{Ca}^{2+}$ influx to the increase of $\left[\mathrm{Ca}^{2+}\right]_{\mathrm{i}}$. The glucose concentration was $10 \mathrm{mM}$, since the insulinotropic effect of the fluoroquinolones was only seen at this concentration.

$100 \mu \mathrm{M}$ lomefloxacin led to a prompt increase of $\left[\mathrm{Ca}^{2+}\right]_{\mathrm{i}}$ which reached a plateau value close to the steady state of a $\mathrm{K}^{+}$depolarization, whereas norfloxacin had only a slight increasing effect (Fig. 8A). D600 reduced the $\left[\mathrm{Ca}^{2+}\right]_{\mathrm{i}}$ levels both in the presence of lomefloxacin and of norfloxacin, achieving a steady state within $15 \mathrm{~min}$. Remarkably, the withdrawal of norfloxacin, but not of lomefloxacin led to regain of $\left[\mathrm{Ca}^{2+}\right]_{\mathrm{i}}$ levels in the continued presence of D600. The withdrawal of D600 did not affect $\left[\mathrm{Ca}^{2+}\right]_{\mathrm{i}}$.

Gatifloxacin and moxifloxacin induced a strong increase of $\left[\mathrm{Ca}^{2+}\right]_{\mathrm{i}}$ whereas ciprofloxacin was moderately effective (Fig. 8B). After 15 min exposure a steady state was established by each compound. The reduction of the elevated $\left[\mathrm{Ca}^{2+}\right]_{\mathrm{i}}$ levels by $\mathrm{D} 600$ reestablished a prestimulatory level in the presence of ciprofloxacin, in the presence of 
gatifloxacin and moxifloxacin only an incomplete reduction was achieved. At the end of the perifusion the $\left[\mathrm{Ca}^{2+}\right]_{\mathrm{i}}$ values were closely similar for all three compounds. Perifusion with 100 $\mu \mathrm{M}$ of the N1-aryl fluoroquinolones $\mathrm{C} 1$ and $\mathrm{C} 2$ increased $\left[\mathrm{Ca}^{2+}\right]_{\mathrm{i}}$ to a plateau value close to the steady state of the preceding $\mathrm{K}^{+}$depolarization, whereas compound $\mathrm{C} 3$ was nearly ineffective and $\mathrm{C} 4$ was of intermediate efficacy. In each case the increased $\left[\mathrm{Ca}^{2+}\right]_{\mathrm{i}}$ levels were diminished by the addition of D600 (data not shown).

In B-cells from SUR1 Ko islets lomefloxacin, gatifloxacin (Fig. 8C) and C2 increased the net Fura ratio. In each case D600 caused a clear reduction. Wash-out of the fluoroquinolones led, after a marked transient reduction, to a minor reduction which was not affected by the wash-out of D600. The values at the end of the perifusion corresponded to those at the beginning.

\subsection{Fluoroquinolone-induced increases of $\left[\mathrm{Ca}^{2+}\right]_{i}$ at basal glucose concentration}

In the presence of $5 \mathrm{mM}$ glucose $100 \mu \mathrm{M}$ gatifloxacin did not cause an increase in the $\left[\mathrm{Ca}^{2+}\right]_{\mathrm{i}}$ levels whereas $40 \mathrm{mM} \mathrm{KCl}$ was effective when added prior to gatifloxacin and also when added during the gatifloxacin perifusion (Fig. 9A). When the gatifloxacin concentration was raised from 100 to $500 \mu \mathrm{M}$ in the presence of $5 \mathrm{mM}$ glucose a clear increase in $\left[\mathrm{Ca}^{2+}\right]_{\mathrm{i}}$ was observed The comparatively large SEM ranges of this response are due to heterogeneity at the single cell level (Fig. 9B).

\section{Discussion}

This study shows that the enhancement of insulin secretion is a group effect of fluoroquinolones and depends on their ability to block $\mathrm{K}_{\mathrm{ATP}}$ channels in pancreatic B-cells. Structurally, it is determined by a combination of several substituents which may affect both membrane permeability and target affinity. Surprisingly, the fluoroquinolones did not initiate insulin secretion, but rather enhanced the secretory response when the glucose concentration was stimulatory by itself. Theoretically, this feature precludes an inappropriate insulin secretion in the presence of a basal glucose concentration and would be a desirable property of an antidiabetic agent. It is thus necessary to assume that as yet unidentified factors may exist which potentiate the insulinotropic effect in the presence of a basal glucose concentration and finally induce hypoglycemia.

\section{Characteristics of fluoroquinolone-induced insulin secretion}

The effect of the clinically relevant fluorquinolones, gatifloxacin, ciprofloxacin and moxifloxacin, was initially characterized in the presence of $10 \mathrm{mM}$ glucose, because this moderate stimulatory glucose concentration amplifies the response to non-nutrients [9] and thus permits easier detection of different efficacies. The rank order of efficacy was: gatifloxacin $>$ moxifloxacin $>$ ciprofloxacin $>$ control. However, the secretion caused by moxifloxacin or ciprofloxacin was still increasing at the beginning of the wash-out period. In 
view of the slow kinetics of the fluoroquinolones, secretion measurements based on static incubations $[7,11]$ may underestimate the insulinotropic efficacy.

Surprisingly, none of the fluoroquinolones stimulated insulin secretion in the presence of a basal glucose concentration $(5 \mathrm{mM})$, but raising the glucose concentration from 5 to 10 $\mathrm{mM}$ revealed the insulinotropic effect. Thus, the insulinotropic effect of the fluoroquinolones is not an initiation of insulin secretion, but rather an enhancement of the stimulatory effect of B-cell nutrients. Our observation is in apparent contrast to data of Saraya et al [11] who had found a stimulatory effect of $300 \mu \mathrm{M}$ gatifloxacin or temafloxacin on mouse islets in the presence of $5.5 \mathrm{mM}$ glucose. Similar to our results, Maeda et al. [7] found no effect of 100 $\mu \mathrm{M}$ lomefloxacin on rat islets in the presence of a basal glucose concentration $(3 \mathrm{mM})$, but a threefold increase was noted when lomefloxacin was used at the exceedingly high concentration of $1 \mathrm{mM}$. The glucose dependence of the insulinotropic effect may therefore be a concentration-dependent phenomenon. In principle, such a dependence on the presence of nutrient secretagogues also applies for the insulinotropic effect of the sulfonylureas, the prototypical class of $\mathrm{K}_{\mathrm{ATP}}$ channel blockers [21], but it is generally agreed that sulfonylureas stimulate insulin secretion in the presence of a basal glucose concentration and, at high concentrations, even in the absence of glucose [22].

Another unexpected observation was that the three clinically relevant compounds appeared to be similarly effective as enhancers once the glucose concentration was raised to a stimulatory level. This in marked contrast to the initial experiments where the glucose concentration was kept constant at $10 \mathrm{mM}$, most likely because in these experiments the perifusion time was to short permit a steady state with each compound. We thus conclude that at $100 \mu \mathrm{M}$ all three fluoroquinolones are in principle effective enhancers of insulin secretion, moxifloxacin being somewhat less effective than cipro- and gatifloxacin. In fact, in earlier clinical pharmacological studies on healthy and diabetic individuals, gatifloxacin was found to have the same modest effects on glucose homeostasis as ciprofloxacin and was therefore regarded as safe $[23,24]$.

The inability of lomefloxacin, gatifloxacin and the N1-arylfluoroquinolone C2 to increase insulin release from SUR1 Ko islets, which do not have functional $\mathrm{K}_{\mathrm{ATP}}$ channels [25], strongly suggests that the block of $\mathrm{K}_{\mathrm{ATP}}$ channels is indispensable for the insulinotropic effect. Fluoroquinolones may have effects on the B-cell in addition to $\mathrm{K}_{\mathrm{ATP}}$ channel blockade, but not effects which can stimulate insulin secretion independently of the $\mathrm{K}_{\mathrm{ATP}}$ channel activity. It is unclear whether the decrease of insulin content by gatifloxacin $[17,26]$ is such an additional effect, since sulfonylureas are also able to degranulate B-cells [27]

\section{Depolarizing effect}

The B-cell membrane potential was measured as a general parameter of the triggering pathway of insulin secretion [9]. The difference between the marked depolarizing effect of lomefloxacin and the modest effect of norfloxacin in our experiments is in parallel with the 
different ability to enhance insulin secretion and fits to the earlier measurements of $\mathrm{K}_{\mathrm{ATP}}$ channel activity in insulin secreting RINm5F cells, where norfloxacin was nearly ineffective [10]. Also, the comparatively slow kinetic corresponded to the kinetics of the $\mathrm{K}_{\mathrm{ATP}}$ channel block and of secretion enhancement.

However, the correspondence between KATP channel block and depolarizing effect was incomplete. E.g., fluoroquinolones $\mathrm{C} 1$ and $\mathrm{C} 3$ effectively depolarized the plasma membrane, but had only modest effects on KATP channel activity under closely similar conditions [28]. Also, there were obvious discrepancies between the depolarizing effect and the effect on secretion. E.g., the fluoroquinolone-induced depolarization was virtually irreversible, whereas the secretion enhancement showed a slow but unmistakable reversibility. Remarkably, the KATP channel opener diazoxide, at a maximally effective concentration had at best a modest repolarizing effect, but was able to abolish the insulinotropic effect.

The results obtained in the perforated patch mode (i.e. using metabolically intact Bcells exposed to $5 \mathrm{mM}$ glucose) resolved several of these contradictions. Here, $100 \mu \mathrm{M}$ of ciprofloxacin, gatifloxacin and moxifloxacin were virtually ineffective, corresponding to the lack of insulinotropic effect at $5 \mathrm{mM}$ glucose. In the same experiments, the sulfonylurea tolbutamide and the imidazoline efaroxan induced depolarizations with action potentials. These compounds were used at a concentration which inhibits B-cell KATP channel activity by about $85 \%$ [29], which is comparable to the effect of $100 \mu \mathrm{M}$ gatifloxacin on reconstituted KATP channels [11]. While tolbutamide closes these channels by binding to the regulatory subunit, SUR1 [12], efaroxan, like the fluoroquinolones, inhibits KATP channels by binding to the pore-forming unit, Kir 6.2 [29].

The loss of potency in the perforated patch mode (as compared to the whole cell mode) may be explained by the hypothesis that the inhibition of KATP channel activity by fluoroquinolones is susceptible to negative modulation by endogenous compounds which are present in metabolically intact B-cells, but not in open B-cells (whole cell mode), where the cytosol is washed out by the pipette solution [30]. This hypothesis would also explain why diazoxide which was unable to antagonize the fluoroquinolones in the whole cell mode, but strongly antagonized the effect of gatifloxacin in the perforated patch mode, which corresponds to the secretion measurements.

In this context, the observation by Saraya et al [11] that gatifloxacin was more potent to block reconstituted Kir6.2/SUR1 channels in HEK cells than to block native $\mathrm{K}_{\text {ATP }}$ channels in MIN6m9 cells can be seen as indirect evidence for the existence of negative modulators in insulin-secreting cells. MgADP, which acts on the SUR subunit [12] is the prototypical endogenous $\mathrm{K}_{\mathrm{ATP}}$ channel opener. It has been shown that the $\mathrm{K}_{\mathrm{ATP}}$ channel block exerted at Kir6.2 by imidazolines can be antagonized by nucleoside diphosphates under nearphysiological conditions [31].

\section{Effects on the cytosolic calcium concentration}


So far there have been no measurements of fluoroquinolone-induced $\left[\mathrm{Ca}^{2+}\right]_{\mathrm{i}}$ changes in B-cells because the endogenous fluorescence of the fluoroquinolones [32] interferes with the Fura-fluorescence. The use of D600 confirmed that the $\left[\mathrm{Ca}^{2+}\right]_{\mathrm{i}}$ increase was due to depolarization-induced influx of $\mathrm{Ca}^{2+}$ via L-type $\mathrm{Ca}^{2+}$ channels [33]. The marked $\left[\mathrm{Ca}^{2+}\right]_{\mathrm{i}}$ increase by gatifloxacin in the presence of $10 \mathrm{mM}$ glucose fits to the secretory characteristics, whereas the moderate but continuing $\left[\mathrm{Ca}^{2+}\right]_{\mathrm{i}}$ increase by ciprofloxacin and the magnitude of the moxifloxacin-induced increase of $\left[\mathrm{Ca}^{2+}\right]_{\mathrm{i}}$ were unexpected. On the other hand, these observations concur with the marked enhancing effect of ciprofloxacin and moxifloxacin on secretion when the glucose concentration was raised to a stimulatory level (Fig. 4).

The moderate $\left[\mathrm{Ca}^{2+}\right]_{\mathrm{i}}$ increase by fluoroquinolones in islet cells from SUR1 Ko mice, which do not have functional $\mathrm{K}_{\mathrm{ATP}}$ channels, suggests that fluoroquinolones may have additional sites of action by which $\left[\mathrm{Ca}^{2+}\right]_{\mathrm{i}}$ is affected. The decrease of $\left[\mathrm{Ca}^{2+}\right]_{\mathrm{i}}$ in response to D600 implicates $\mathrm{Ca}^{2+}$ influx via L-type $\mathrm{Ca}^{2+}$ channels. However, SUR1 Ko B-cells have a chronically elevated $\left[\mathrm{Ca}^{2+}\right]_{\mathrm{i}}$ because the smaller $\mathrm{K}^{+}$conductance leads to a partial depolarization [34] .Since lomefloxacin and gatifloxacin did not enhance insulin secretion from SUR1 Ko islets [7] it appears that this increase of $\left[\mathrm{Ca}^{2+}\right]_{\mathrm{i}}$ is not related to stimulated secretion. Dissociations between $\left[\mathrm{Ca}^{2+}\right]_{\mathrm{i}}$ increases measured by Fura and stimulation of secretion have been found earlier, e.g. when $\left[\mathrm{Ca}^{2+}\right]_{\mathrm{i}}$ increase was caused by inhibition of mitochondrial metabolism [35].

\section{Structure - activity relations}

With regard to the structure activity relationships the compounds tested in this study can be subdivided in three groups: i) compounds which have an ethyl substituent at N1, ii) cyclopropyl-substituted compounds and iii) fluorophenyl-substituted compounds. The cyclopropyl-substituted fluoroquinolones, namely ciprofloxacin, moxifloxacin and gatifloxacin, make up the clinically most relevant compounds [36]. Each of these groups contained effective stimulators of insulin secretion, even though minor changes of the N1substituent, like different positions of the fluorine at the phenyl ring were functionally relevant. A bulkiness of the substituent at N7 (e.g. dimethylpiperazine vs unsubstituted piperazine) and a fluorine atom or a methoxy group at position C8 appeared to favour biological activity. Since the same is true for the antiinfective potency [36] the latter parameters may be relevant for the membrane passage and intracellular accumulation, but not for target selectivity. Apparently, the insulinotropic effect is not easily separable from the basic features of systemically active fluoroquinolones.

\section{Correlation with risk of hypoglycemia}

There is only an incomplete correspondance between the present experimental data and the clinical risk of hypoglycemia. Recently, two epidemiological reports have been 
published which permit quantitative estimates. In the first report [1], gatifloxacin was identified to cause the vast majority of hypoglycemias with levofloxacin being a distant second. Ciprofloxacin and moxifloxacin were apparently not associated with an increased risk. In another study, evaluating spontaneous adverse events reports, gatifloxacin was again the leading cause of hypoglycemias, but there was also a sizable portion of hypoglycemias caused by moxifloxacin, levofloxacin and ciprofloxacin, roughly in the proportion of 100:10:2:1 [2]. This rank order is not reflected by the insulinotropic efficacy in vitro. The feature that sets gatifloxacin apart from the other clinically relevant compounds tested here is the comparatively fast onset of action, a feature shared with lomefloxacin and the N1-aryl fluoroquinolone $\mathrm{C} 2$.

The different hypoglycemic risk of ciprofloxacin, gatifloxacin, and moxifloxacin is also not explained by pharmacokinetic data. The doses which are required for antibacterial effects are similar for these three compounds. A single dose of $250 \mathrm{mg}$ gave peak plasma concentrations of $1.2 \mu \mathrm{g} / \mathrm{ml}$ for ciprofloxacin, 1.7 and $2.2 \mu \mathrm{g} / \mathrm{ml}$ for gatifloxacin and moxifloxacin, respectively [37]. Since this corresponds roughly to $5 \mu \mathrm{M}$, it is unlikely that extracellular concentrations as high as $100 \mu \mathrm{M}$ or $500 \mu \mathrm{M}$ will ever occur in fluoroquinolonetreated patients. A different intracellular accumulation of the fluoroquinolones may play a role. However, it must be noted that the hypoglycemias mostly occur at the beginning of a fluoroquinolone therapy [38], whereas after several days of therapy, when different intracellular accumulation may be more important, hyperglycemias are more frequent. While hyperglycemias may involve extrapancreatic effects [39], our observation that the fluoroquinolones at $100 \mu \mathrm{M}$ were ineffective to stimulate insulin secretion in the presence of a basal glucose concentration leads to the provocative question why these compounds are hypoglycemic at all. Intriguingly, diabetes is a strong risk factor, independently of a sulfonylurea or insulin therapy [40]

In conclusion, it seems that the $\mathrm{K}_{\mathrm{ATP}}$ channel-blocking effect is a necessary but not a sufficient condition for the hypoglycemic side effect of the fluoroquinolones. In particular, the prominent role of gatifloxacin is not sufficiently explained. Up to a fluoroquinolone concentration of at least $100 \mu \mathrm{M}$, which is 20 fold above the peak plasma concentrations [36,37], the presence of a basal glucose concentration precludes the depolarization of metabolically intact B-cells and the ensuing stimulation of insulin secretion. We hypothesize that at therapeutically relevant concentrations of the fluoroquinolones, their $\mathrm{K}_{\mathrm{ATP}}$ channelblocking effect has to be potentiated by as yet unidentified factors to stimulate insulin secretion in the presence of a basal glucose concentration and to finally induce hypoglycemia. These factors may also be relevant for the markedly different frequency with which fluoroquinolones induce hypoglycemias. 


\section{Acknowledgements}

1 assistance by Verena Lier-Glaubitz and Sabine Warmbold is gratefully acknowledged. 


\section{References}

[1] Park-Wyllie LY, Juurlink D, Kopp A, Shah BR, Stukel T, Stumpo C et al. Outpatient gatifloxacin therapy and dysglycemia in older adults. N Engl J Med 2006; 354: 1-10.

[2] Frothingham R. Glucose homeostasis abnormalities associated with the use of gatifloxacin. Clin Infect Dis 2005; 41: 1269-1276.

[3] Roberge RJ, Kaplan R, Frank P, Fore C. Glyburide-ciprofloxacin interaction with resistant hypoglycaemia. Ann Emerg Med 2000; 36: 160-163.

[4] Menzies DJ, Dorsainvil PA, Cunha BA, Johnson DH. Severe and persistent hypoglycaemia due to gatifloxacin interaction with oral hypoglycaemic agents. Am $\mathbf{J}$ Med 2002; 113: 232-234.

[5] Bhasin R, Arce FC, Pasmantier R. Hypoglycemia associated with the use of gatifloxacin. Am J Med Sci 2005; 330: 250-253.

[6] Mohr JF, McKinnon, PS, Peymann PJ, Kenton I, Septimus E, Okhuysen PC. A retrospective comparative evaluation of dyglycemias in hospitalized patients receiving gatifloxacin, levofloxacin ciprofloxacin and ceftriaxone. Pharmacotherapy 2005; 25: 1303-1309.

[7] Maeda N, Tamgawa T, Niki I, Miura H, Ozawa K, Watanabe G. Increase in insulin release from rat pancreatic islets by quinolone antibiotics. Br J Pharmaco1 1996; 117: 372-376.

[8] Ashcroft FM, Rorsman P. Electrophysiology of the pancreatic beta-cell. Prog Biophys Mol Biol 1990; 54: 87-143.

[9] Henquin JC. Triggering and amplifying pathways of regulation of insulin secretion by glucose. Diabetes 2000; 49: 1751-1760.

[10] Zünkler BJ, Wos M. Effects of lomefloxacin and norfloxacin on pancreatic beta-cel ATP-sensitive $\mathrm{K}^{+}$channels. Life Sci 2003; 73: 429-435.

[11] Saraya A, Yokokura M, Gonoi T, Seino S. Effects of fluoroquinolones on insulin secretion and B-cell ATP-sensitive $\mathrm{K}^{+}$channels. Eur J Pharmacol 2004; 497: 111-117.

[12] Babenko AP, Aguilar-Bryan L, Bryan J. A view of SUR/Kir6.X, K ATP $_{\text {channels. Ann }}$ Rev Physiol 1998; 60: 667-687.

[13] Haruhara N, Niwa H, Kitayama S, Sakai N. Two cases of drug-induced hypoglycemic coma. J Tomakomai City Hospital 2000; 14: 41-46.

[14] Friedrich LV, Dougherty R. Fatal hypoglycemia associated with levofloxacin. Pharmacotherapy 2004; 24: 1807-1812.

[15] Beste LA, Mersfelder TL. Hyperglycemia and gatifloxacin: a case report and summary of current literature Am J Geriatr Pharmacother 2005; 3: 262-265.

[16] Blommel AL, Lutes RA. Severe hyperglycemia during renally adjusted gatifloxacin therapy. Ann Pharmacother 2005; 39: 1349-1352.

[17] Tomita T, Onishi M, Kimura Y, Kihira K. Gatifloxacin induces insulin release and intracellular insulin secretion pancreatic islet cells. Biol Pharm Bull 2007; 30: 644-647. 
[18] Jürgens J, Schedletzky H, Heisig P, Seydel JK, Wiedemann B, Holzgrabe U. Synthesis and biological activities of new N1-aryl substituted quinolone antibacterials. Arch Pharm Pharm Med Chem 1996; 329:179-190.

[19] Smith PA, Ashcroft FM, Rorsman P. Simultaneous recording of glucose-dependent electrical activity and ATP-regulated $\mathrm{K}^{+}$-currents in isolated mouse pancreatic betacells. FEBS Lett 1990; 261: 187-190.

[20] Zünkler BJ, Lins S, Ohno-Shosaku T, Panten U. Cytosolic ADP enhances the sensitivity to tolbutamide of ATP-dependent $\mathrm{K}^{+}$-channels from pancreatic B-cells. FEBS Lett 1988; 239: 241-244.

[21] Henquin JC. A minimum of fuel is necessary for tolbutamide to mimic the effects of glucose on electrical activity in pancreatic $\beta$-cells. Endocrinology 1998; 139: 993-998.

[22] Panten U, Zunkler BJ, Scheit S, Kirchhoff K, Lenzen S. regulation of energy metabolism in pancreatic islets by glucose and tolbutamide. Diabetologia 1986; 29: 64854.

[23] Gajjar DA, Lacreta FP, Kollia GD, Stolz RR, Berger S, Smith WB et al. Effect of multiple-dose gatifloxacin or ciprofloxacin on glucose homeostasis and insulin production in patients with non insulin-dependent diabetes mellitus maintained with diet and exercise. Pharmacotherapy 2000; 20: 76S-86S.

[24] Gajjar DA, Lacreta FP, Uderman HD, Kollia GD, Duncan G, Birkhofer MJ et al. A dose-escalation study of the safety, tolerability and pharmacokinetics of intravenous gatifloxacin in healthy adult men. Pharmacotherapy 2000; 20: 49S-58S.

[25] Seghers V, Nakazaki M, Demayo F, Aguilar-Bryan L, Bryan J. Surl knockout mice. A model for $\mathrm{K}_{\mathrm{ATP}}$ channel-independent regulation of insulin secretion. J Biol Chem 2000; 275: 9270-9277.

[26] Yamada C, Nagashima K, Takahashi A, Ueno H, Kawasaki Y, Yamada Y, Seino Y, Inagaki N. Gatifloxacin acutaely stimulates insdulin secretion and chronically suppresses insulin biosynthesis. Eur J Pharmacol 2006; 553: 67-72.

[27] Rustenbeck I. Desensitization of insulin secretion. Biochem Pharmacol 2002; 63: 19211935.

[28] Zünkler BJ, Claaßen S, Wos-Maganga M, Rustenbeck I, Holzgrabe U. Effects of fluoroquinolones on HERG channels and on pancreatic $\beta$-cell ATP-sensitive $\mathrm{K}^{+}$ channels. Toxicology 2006; 228: 239-248.

[29] Bleck C, Wienbergen A, Rustenbeck I. Essential role of the imidazoline moiety in the insulinotropic effect but not the $\mathrm{K}_{\mathrm{ATP}}$ channel-blocking effect of imidazolines; $\mathrm{A}$ comparison of the effect of efaroxan and its imidazole analogue, KU14R. Diabetologia 2005; 48: 2567-2575.

[30] Strauss U, Herbrik M, Mix M, Schubert R, Rolfs A. Whole-cell patch clamp: true perforated or spontaneous conventional recordings? Pflügers Arch - Eur J Physiol 2001; 442: 634-638.

[31] Wienbergen A, Bleck C, Grosse Lackmann T, Rustenbeck I. Antagonism of the insulinotropic action of first generation imidazolines. Biochem Pharmacol 2007; 73: 94102. 
[32] Idowu O, Peggins JO. Simple, rapid determination of enrofloxacin and ciprofloxain in bovine milk and plasma by HPLC with fluorescence detection. J Pharm Biomed Anal 2004; 35: 143-153.

[33] Dryselius S, Grapengiesser E, Hellman B, Gylfe E. Voltage-dependent entry and generation of slow $\mathrm{Ca}^{2+}$ oscillations in glucose-stimulated pancreatic $\beta$-cells. Am $\mathrm{J}$ Physiol 1999; 276: E512-E518.

[34] Nenquin M, Szollosi A, Aguilar-Bryan L, Bryan J, Henquin JC. Both triggering and amplifying pathways contribute to fuel-induced insulin secretion in the absence of sulfonylurea receptor-1 in pancreatic beta-cells. J Biol Chem 2004; 279: 32316-32324.

[35] Rustenbeck I, Herrmann C und Grimmsmann T. Energetic requirement of insulin secretion distal to $\mathrm{Ca}^{2+}$ influx. Diabetes 1997; 46: 1305-1311.

[36] Van Bambeke F, Michot JM, Van Eldere J, Tulkens PM. Quinolones in 2005: an update. Clin Microbiol Infect 2005; 11: 256-280

[37] Lode H. Evidence of different profiles of side effects and drug-drug-interactions among the quinolones - the pharmacokinetic standpoint. Chemotherapy 2001; 47(suppl 3):2431

[38] Khovidunkit W, Sunthornyothin S. Hypoglycemia, Hyperglycemia, and Gatifloxacin. Ann Intern Med 2004; 12: 966-969.

[39] Ishiwata Y, Sanada Y, Yasuhara M. Effects of gatifloxacin on serum glucose concentration in normal and diabetic rats. Biol Pharm Bull 2006; 29: 527-531

[40] LaPlante KL, Mersfelder TL, Ward K, Quilliam BJ. Prevalence of and risk factors for dysglycemia in patients receiving gatifloxacin and levofloxacin in an outpatient setting. Pharmacotherapy 2008; 28: 82-89.

[41 ] Holzgrabe U, Steinert M. N1-phenyl substituted 4-quinolones of tuberculostatic activity. Pharmazie 2001; 56: 850-51. 


\section{Legends to figures}

Fig. 1 - Structural formulas of fluoroquinolones: (A) lomefloxacin; (B) ciprofloxacin, (C) gatifloxacin. Lomefloxacin and norfloxacin contain an ethyl-substituent at N1, whereas ciprofloxacin, gatifloxacin and moxifloxacin contain a cyclopropyl-substituent at this position. A substitution with a mono- or difluorinated aryl moiety at N1 (D) gives compounds with enhanced antituberculotic activity [41]. All of these substituents were found to be compatible with an insulinotropic effect. Methylation of the piperazinyl-moiety and substitution at C8 appear to favor the insulinotropic effect, but are not indispensable as can be seen from the effect of ciprofloxacin.

Fig. 2 - Fura-2 measurement of the free cytosolic calcium concentration $\left[\mathrm{Ca}^{2+}\right]_{\mathrm{i}}$ in single pancreatic B-cells with (closed circles) and without (open circles) correction for the fluoroquinolone autofluorescence. Cultured single B-cells were perifused with Krebs-Ringer medium containing $10 \mathrm{mM}$ glucose. Voltage-dependent $\mathrm{Ca}^{2+}$ influx was tested by a $10 \mathrm{~min}$ perifusion with $40 \mathrm{mM} \mathrm{KCl}$. From $30 \mathrm{~min}$ to $60 \mathrm{~min}$ the medium contained $100 \mu \mathrm{M}$ norfloxacin and from 45 to $70 \mathrm{~min} 50 \mu \mathrm{M}$ D600. The data are means \pm SEM of 27 Fura loaded cells (open circles) and 29 sham-loaded cells, the fluorescence emission of which was subtracted from that of loaded cells to calculate a net fluorescence ratio (closed circles). This procedure affected the fluoroquinolone- but not the KCl-induced increase of the Fura fluorescence ratio.

Fig. 3 - Comparison of the insulinotropic efficacy of fluoroquinolones in the presence of 10 $\mathrm{mM}$ glucose (A) Comparison of lomefloxacin and norfloxacin. Freshly isolated mouse islets were perifused with Krebs-Ringer medium containing $10 \mathrm{mM}$ glucose throughout. From 60 min to $75 \mathrm{~min}$ and again from $95 \mathrm{~min}$ to $110 \mathrm{~min} 100 \mu \mathrm{M}$ of either lomefloxacin or norfloxacin was added to the perifusion medium. In the first set of experiments (closed circles) the lomefloxacin exposure preceded the norfloxacin exposure, separated by a washout period of $20 \mathrm{~min}$, whereas in the other set (open circles) norfloxacin preceded lomefloxacin. Obviously, a steady state-level of secretion was not reached with the $15 \mathrm{~min}$ exposure to lomefloxacin. Values are means of 3 experiments. (B) Comparison of gatifloxacin, ciprofloxacin and moxifloxacin. Freshly isolated mouse islets were perifused with Krebs-Ringer medium containing $10 \mathrm{mM}$ glucose throughout. From $60 \mathrm{~min}$ to $90 \mathrm{~min}$ the medium contained $100 \mu \mathrm{M}$ of the fluoroquinolones, from 100 to $110 \mathrm{~min}$ the $\mathrm{K}^{+}$ concentration was increased from $4.6 \mathrm{mM}$ to $40 \mathrm{mM}$. Values are means \pm SEM of 4 experiments. To better show the kinetics and the rank order of the insulinotropic effect, the data were normalized with respect to last prestimulatory value. This procedure somewhat distorted the effect size of the subsequent KCl-depolarization. (C) Comparison of N1arylsubstituted fluoroquinolones. Freshly isolated NMRI mouse islets were perifused with 
Krebs-Ringer medium containing $10 \mathrm{mM}$ glucose throughout. From $60 \mathrm{~min}$ to $90 \mathrm{~min}$ the medium contained $100 \mu \mathrm{M}$ of either arylfluoroquinolone $\mathrm{C} 1, \mathrm{C} 2, \mathrm{C} 3$ or $\mathrm{C} 4$. Values are means of 2 experiments.

Fig. 4 - Dependence of the insulinotropic effect of the fluoroquinolones on the glucose concentration. (A) Freshly isolated mouse islets were perifused with Krebs-Ringer medium containing $5 \mathrm{mM}$ glucose for $90 \mathrm{~min}$. From $60 \mathrm{~min}$ to $120 \mathrm{~min}$ the medium contained $100 \mu \mathrm{M}$ of either gatifloxacin, ciprofloxacin or moxifloxacin. From $90 \mathrm{~min}$ to $130 \mathrm{~min}$, in the continued presence of the drugs, the glucose concentration was raised from 5 to $10 \mathrm{mM}$. (B) Same database, here the mean values of each data set were normalized by setting the last prestimulatory value $(60 \mathrm{~min})$ to $100 \%$. Values are means \pm SEM of 4 experiments.

Fig. 5 - Dependence of the insulinotropic effect of the fluoroquinolones on the presence of $\mathrm{K}_{\mathrm{ATP}}$ channels. (A) Freshly isolated islets from NMRI mice or SUR1 Ko mice were perifused with Krebs-Ringer medium containing $10 \mathrm{mM}$ glucose throughout. From $60 \mathrm{~min}$ to $90 \mathrm{~min}$ the medium contained $100 \mu \mathrm{M}$ of either lomefloxacin or N1-aryl fluoroquinolone $\mathrm{C} 2$. Values are means \pm SEM of 3 - 4 experiments. (B) Freshly isolated islets from NMRI mice or SUR1 Ko mice were perifused with Krebs-Ringer medium containing $10 \mathrm{mM}$ glucose throughout. From $60 \mathrm{~min}$ to $120 \mathrm{~min}$ the medium contained $100 \mu \mathrm{M}$ gatifloxacin, from 90 to $120 \mathrm{~min} 300$ $\mu \mathrm{M}$ diazoxide was additionally present. Values are means \pm SEM of 4 or 6 experiments.

Fig. 6 - Depolarization of the membrane potential of mouse pancreatic B-cells by ciprofloxacin (A), moxifloxacin (B), fluoroquinolone $\mathrm{C} 2$ (C) and fluoroquinolone C4 (D). Original registrations of the membrane potential of cultured mouse B-cells using the conventional whole cell-configuration. Initially, the fluoroquinolone concentration was 50 $\mu \mathrm{M}$, which was increased to $100 \mu \mathrm{M}$ when a steady state was apparently reached. In (C) and (D) $500 \mu \mathrm{M}$ tolbutamide was used as a positive control. In (B) and (C) the modest effect of $300 \mu \mathrm{M}$ diazoxide, a maximally effective concentration, is shown. Note lack of effect of tolbutamide but not $\mathrm{KCl}$ after diazoxide exposure (C). Typical registrations of $4-7$ experiments.

Fig. 7 - Comparison of the depolarizing effect of fluoroquinolones on metabolically intact pancreatic B-cells Original registrations of the effect of $100 \mu \mathrm{M}$ of gatifloxacin (A), ciprofloxacin (B) and $500 \mu \mathrm{M}$ gatifloxacin (C) on the membrane potential of mouse pancreatic B-cells in the perforated patch configuration. At $100 \mu \mathrm{M}$ none of the fluoroquinolones elicited a depolarization. Note the effect of $100 \mu \mathrm{M}$ of efaroxan in the presence of $100 \mu \mathrm{M}$ gatifloxacin or ciprofloxacin (A and B). Increasing gatifloxacin concentration from 100 to $500 \mu \mathrm{M}$ led to action potential spiking interrupted by short phases of repolarization (C). Typical registrations of 3 - 4 experiments.

Fig. 8 - Effect of $100 \mu \mathrm{M}$ of fluoroquinolones on the $\left[\mathrm{Ca}^{2+}\right]_{\mathrm{i}}$ in single pancreatic B-cells from normal mice or SUR1 Ko mice. Cultured single B-cells were perifused with Krebs-Ringer 
medium containing $10 \mathrm{mM}$ glucose. Voltage-dependent $\mathrm{Ca}^{2+}$ influx was tested by a $10 \mathrm{~min}$ perifusion with $40 \mathrm{mM} \mathrm{KCl}$. From $30 \mathrm{~min}$ to $60 \mathrm{~min}$ the medium contained $100 \mu \mathrm{M}$ of the fluoroquinolone and from 45 to 70 min $50 \mu \mathrm{M}$ D600. (A) In normal mouse B-cells $100 \mu \mathrm{M}$ lomefloxacin established a steady state $\left[\mathrm{Ca}^{2+}\right]_{i}$ close to the steady state of the $\mathrm{KCl}$ depolarization, whereas norfloxacin was only slightly effective. Values are means \pm SEM of 24 - 28 loaded and 20 - 27 sham-loaded B-cells from 3 or 4 experiments (B) Gatifloxacin and moxifloxacin were strongly effective to raise $\left[\mathrm{Ca}^{2+}\right]_{\text {i }}$, in normal mouse B-cells whereas ciprofloxacin was less effective. Note the incomplete reduction of the gatifloxacin- and moxifloxacin-induced $\left[\mathrm{Ca}^{2+}\right]_{i}$ increase by D600. Values are means \pm SEM of $24-32$ loaded and 19 - 29 sham-loaded B-cells from 3 - 5 experiments. (C) Both lomefloxacin and gatifloxacin induced a moderate rise of $\left[\mathrm{Ca}^{2+}\right]_{i}$ in B-cells from SUR1 Ko mice, which was antagonized by D600. Values are means \pm SEM of 24 - 32 loaded and 19 - 29 sham-loaded Bcells from 3 or 5 experiments.

Fig. 9 - Effect of gatifloxacin on the $\left[\mathrm{Ca}^{2+}\right]_{\mathrm{i}}$ in the presence of a basal glucose concentration. Cultured normal mouse islets or single B-cells therefrom were perifused with Krebs-Ringer medium containing $5 \mathrm{mM}$ glucose. (A) Voltage-dependent $\mathrm{Ca}^{2+}$ influx was tested by a $10 \mathrm{~min}$ perifusion with $40 \mathrm{mM} \mathrm{KCl}$. From $30 \mathrm{~min}$ to $70 \mathrm{~min}$ the medium contained $100 \mu \mathrm{M}$ gatifloxacin and from 50 to 60 min additionally $40 \mathrm{mM} \mathrm{KCl}$. Values are means \pm SEM of 3 loaded and 3 sham-loaded islets from 3 experiments. (B) From $10 \mathrm{~min}$ to $30 \mathrm{~min}$ the medium contained $100 \mu \mathrm{M}$ gatifloxacin and from $30 \mathrm{~min}$ to $50 \mathrm{~min} 500 \mu \mathrm{M}$ gatifloxacin. After washout the basal value of the net Fura fluorescence was established by $50 \mu \mathrm{M}$ D600. Values are means \pm SEM of 26 loaded and 30 sham-loaded B-cells from 4 experiments each. 


\section{Table 1}

Comparison of the depolarizing effect of fluoroquinolones on the membrane potential of mouse pancreatic B-cells.

\begin{tabular}{|l|l|l|l|}
\hline compound & $\begin{array}{l}\text { resting } \\
\text { membrane potential }\end{array}$ & $\begin{array}{l}\text { steady state } \\
\text { depolarization }\end{array}$ & wash-out \\
\hline lomefloxacin & $-67.8 \pm 4.2 \mathrm{mV}(7)$ & $-46.4 \pm 2.4 \mathrm{mV}(7)$ & $-42.8 \pm 4.5 \mathrm{mV}(4)$ \\
\hline norfloxacin & $-72.4 \pm 1.4 \mathrm{mV}(7)$ & $-61.1 \pm 4.7 \mathrm{mV}(7)$ & $-59.0 \pm 6.6 \mathrm{mV}(7)$ \\
\hline ciprofloxacin & $-68.0 \pm 5.0 \mathrm{mV}(4)$ & $-42.6 \pm 6.9 \mathrm{mV}(4)$ & $-38.8 \pm 6.1 \mathrm{mV}(4)$ \\
\hline gatifloxacin & $-73.8 \pm 2.9 \mathrm{mV}(6)$ & $-45.3 \pm 5.6 \mathrm{mV}(6)$ & $-44.8 \pm 7.8 \mathrm{mV}(6)$ \\
\hline moxifloxacin & $-73.4 \pm 2.8 \mathrm{mV}(7)$ & $-64.8 \pm 3.1 \mathrm{mV}(7)$ & $-63.8 \pm 3.9 \mathrm{mV}(5)$ \\
\hline fluoroquinolone C1 & $-65.4 \pm 4.3 \mathrm{mV}(5)$ & $-41.7 \pm 3.9 \mathrm{mV}(5)$ & $-35.6 \pm 6.1 \mathrm{mV}(5)$ \\
\hline fluoroquinolone C2 & $-73.5 \pm 1.4 \mathrm{mV}(6)$ & $-46.2 \pm 6.0 \mathrm{mV}(6)$ & $-51.2 \pm 6.0 \mathrm{mV}(4)$ \\
\hline fluoroquinolone C3 & $-69.4 \pm 2.8 \mathrm{mV}(5)$ & $-46.3 \pm 9.7 \mathrm{mV}(5)$ & $-41.0 \pm 7.2 \mathrm{mV}(5)$ \\
\hline fluoroquinolone C4 & $-67.6 \pm 3.2 \mathrm{mV}(6)$ & $-55.8 \pm 5.4 \mathrm{mV}(6)$ & $-58.7 \pm 9.5 \mathrm{mV}(4)$ \\
\hline
\end{tabular}

The membrane potential of mouse pancreatic B-cells was measured in the conventional whole cell mode as shown in Fig. 6. All compounds were tested at a concentration of $50 \mu \mathrm{M}$. Data are means \pm SEM of the number of experiments given in brackets. All compounds were significantly effective at $50 \mu \mathrm{M}$ ( $\mathrm{p}<0.05$, unpaired t-test), except for moxifloxacin, the effect of which was marginally significant $(p=0.062)$. The mean time required to establish a steady state depolarization was 7.5 minutes, in control experiments (addition of $0.2 \%$ DMSO) the membrane potential decreased spontaneously from $-70.9 \pm 2.8 \mathrm{mV}$ to $-68.0 \pm 4.5 \mathrm{mV}(\mathrm{n}=6)$ during this time. 
A<smiles>CCn1cc(C(=O)O)c(=O)c2cc(F)c(N3CCNC(C)C3)c(F)c21</smiles>

B<smiles>O=C(O)c1cn(C2CC2)c2cc(N3CCNCC3)c(F)cc2c1=O</smiles>

C<smiles>COc1c(N2CCNC(C)C2)c(F)cc2c(=O)c(C(=O)O)cn(C3CC3)c12</smiles>

D<smiles>CC1CN(c2cc3c(cc2F)c(=O)c(C(=O)O)cn3-c2ccccc2F)CC(C)N1</smiles> 


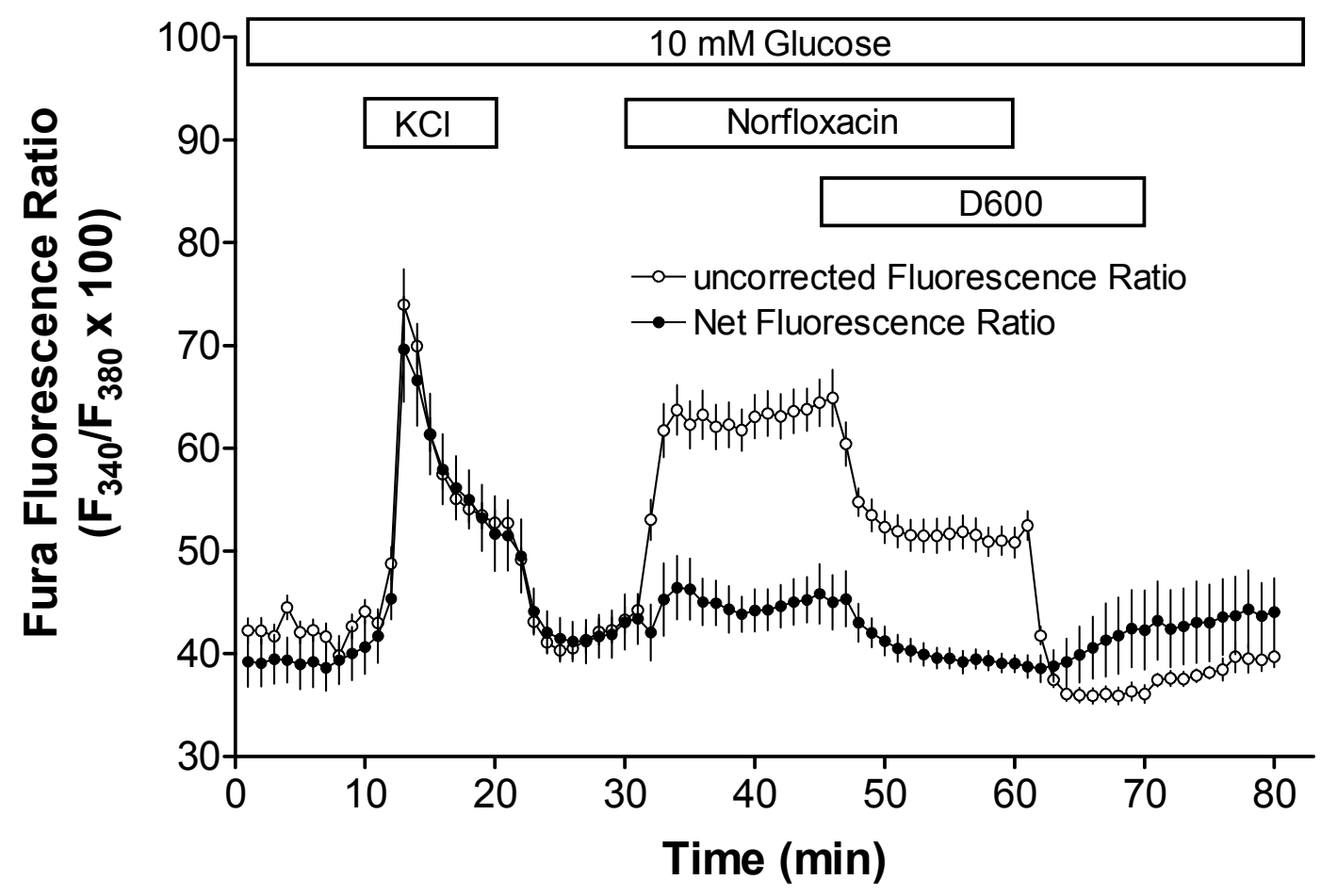



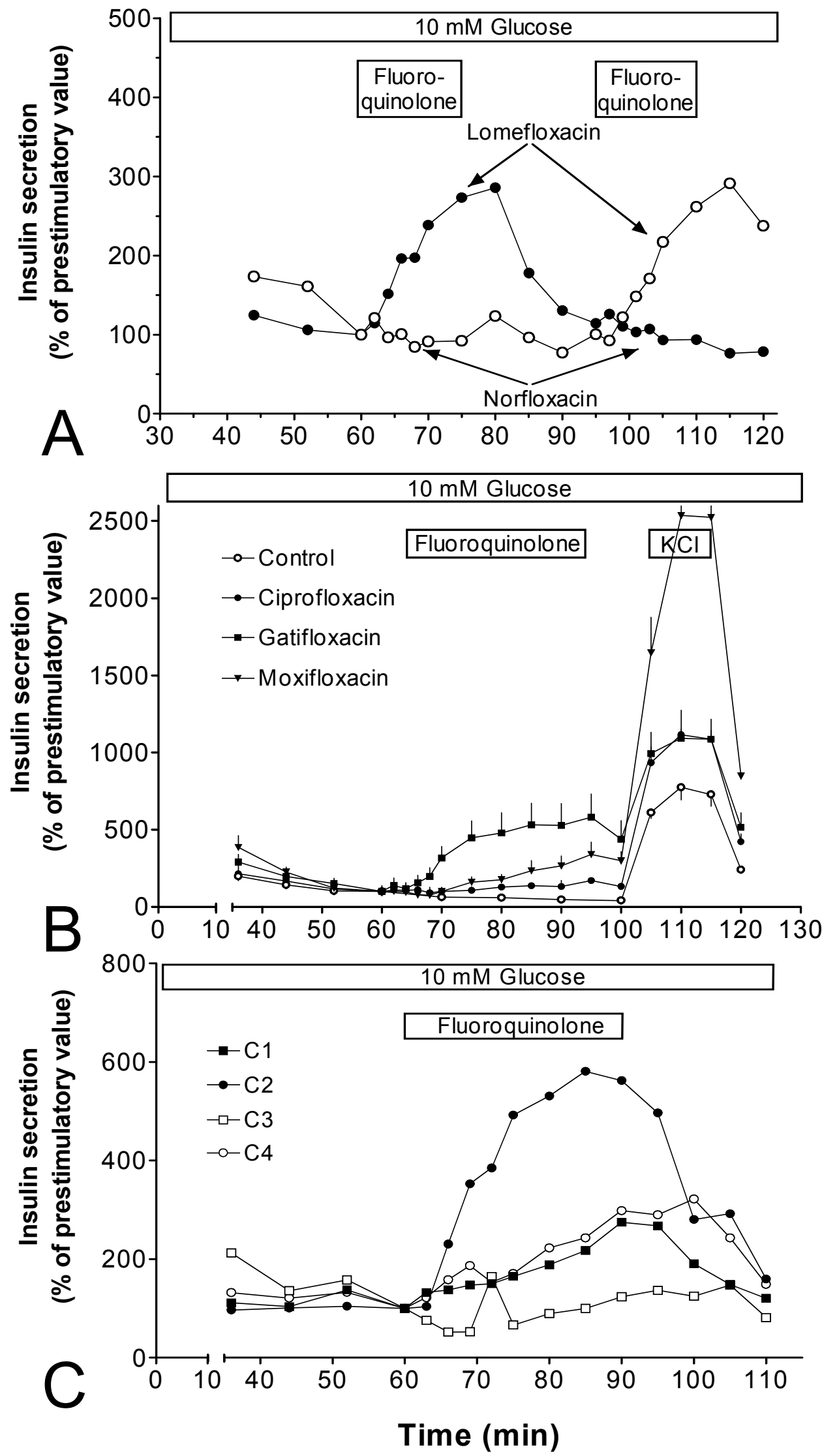

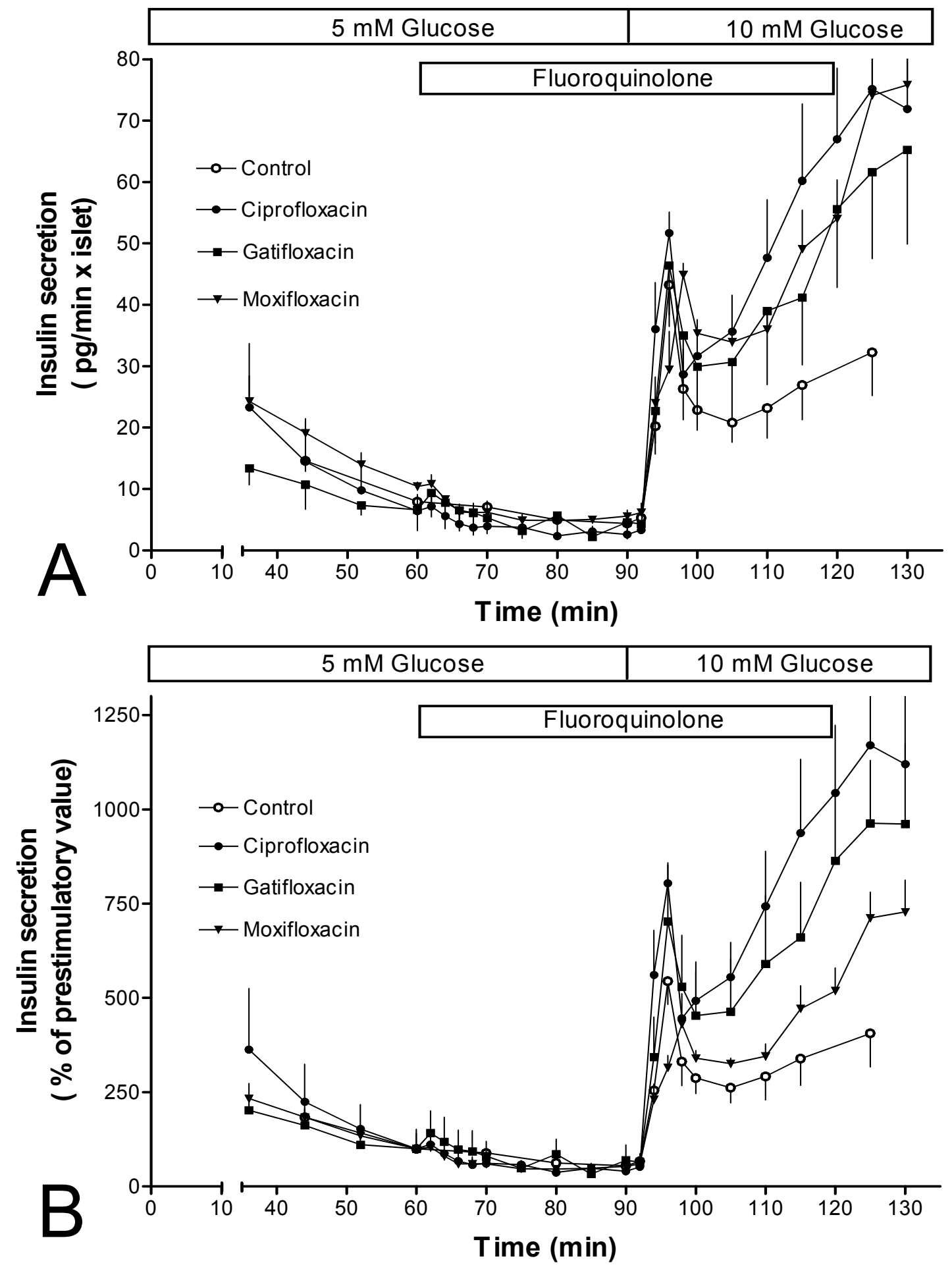

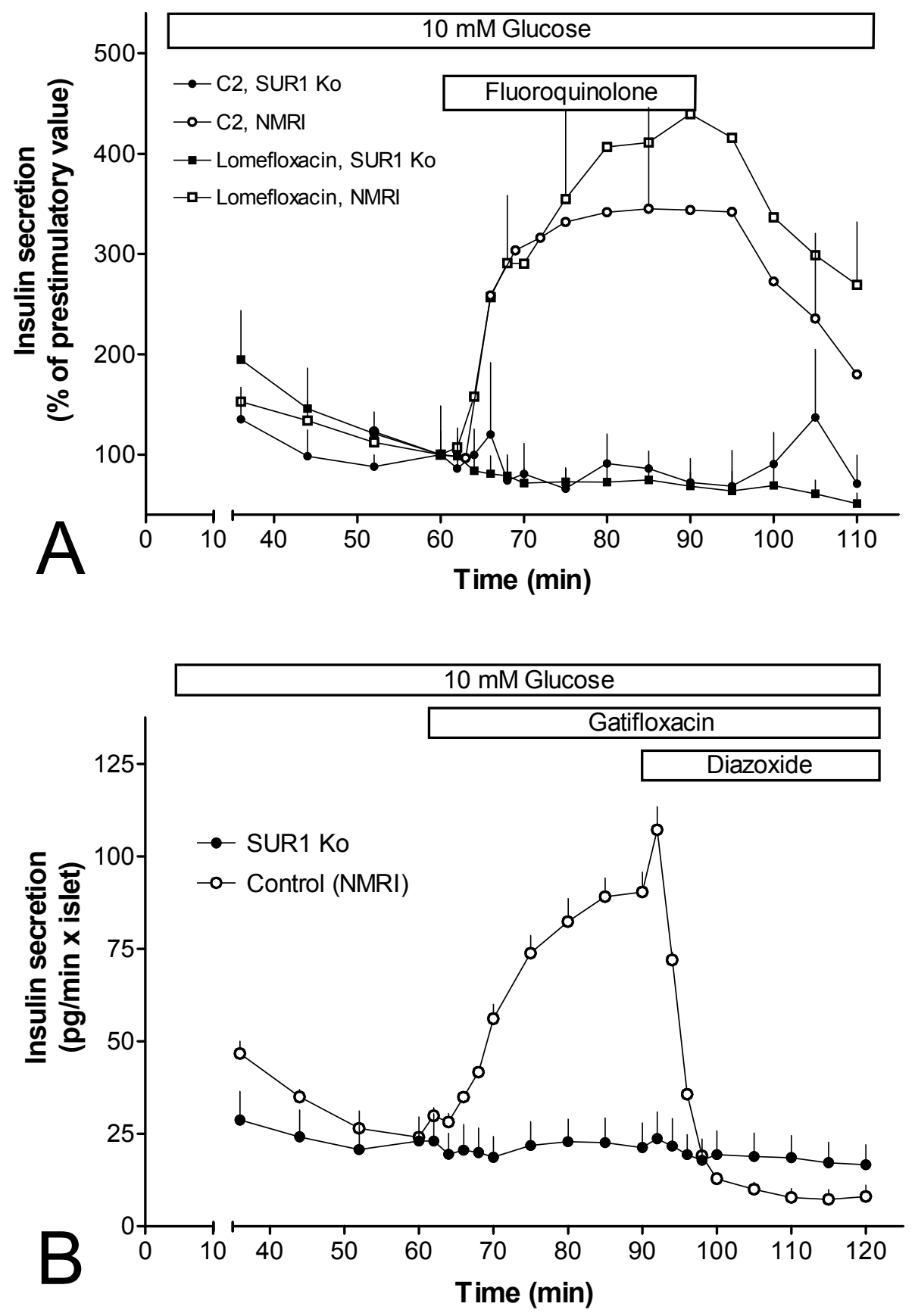

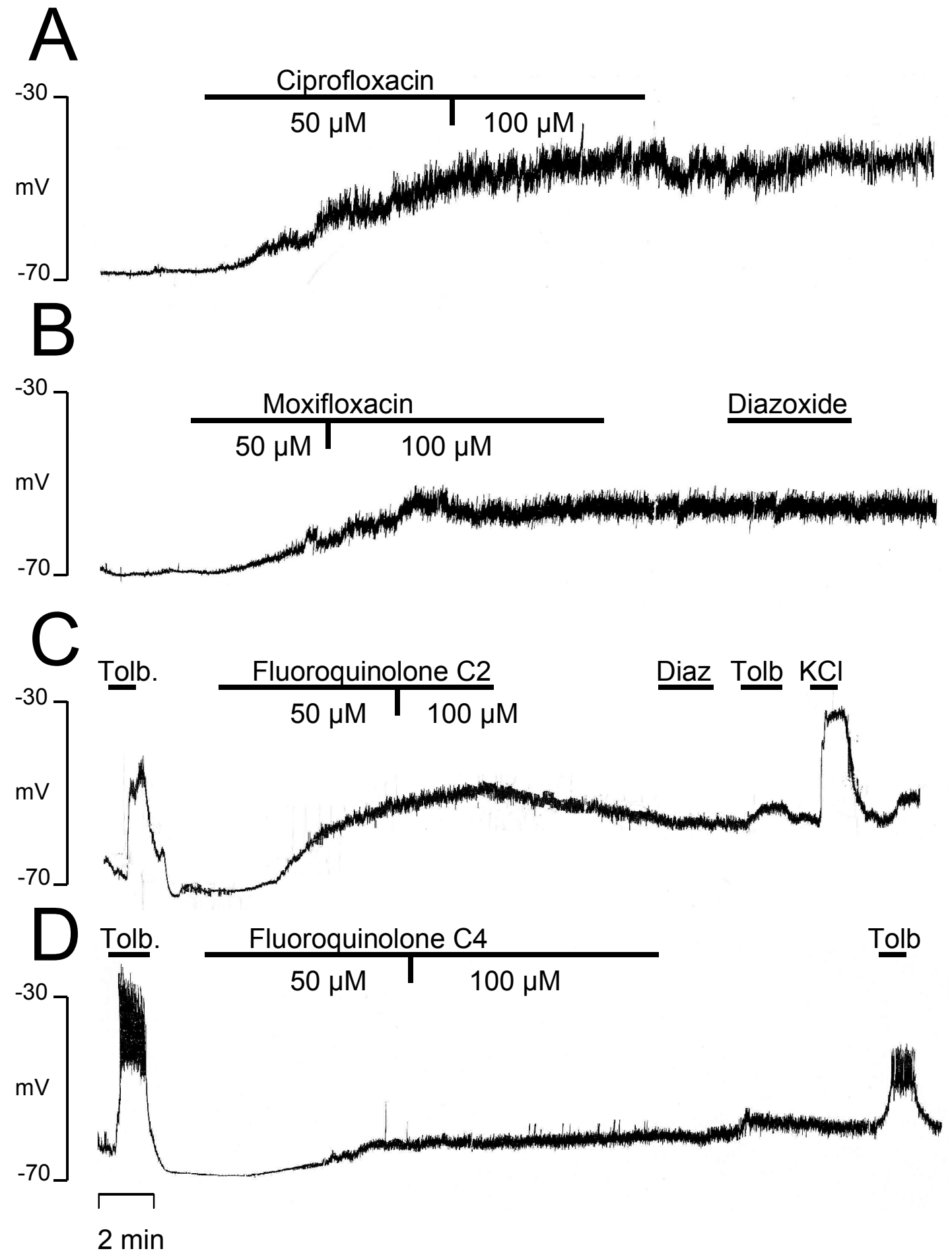

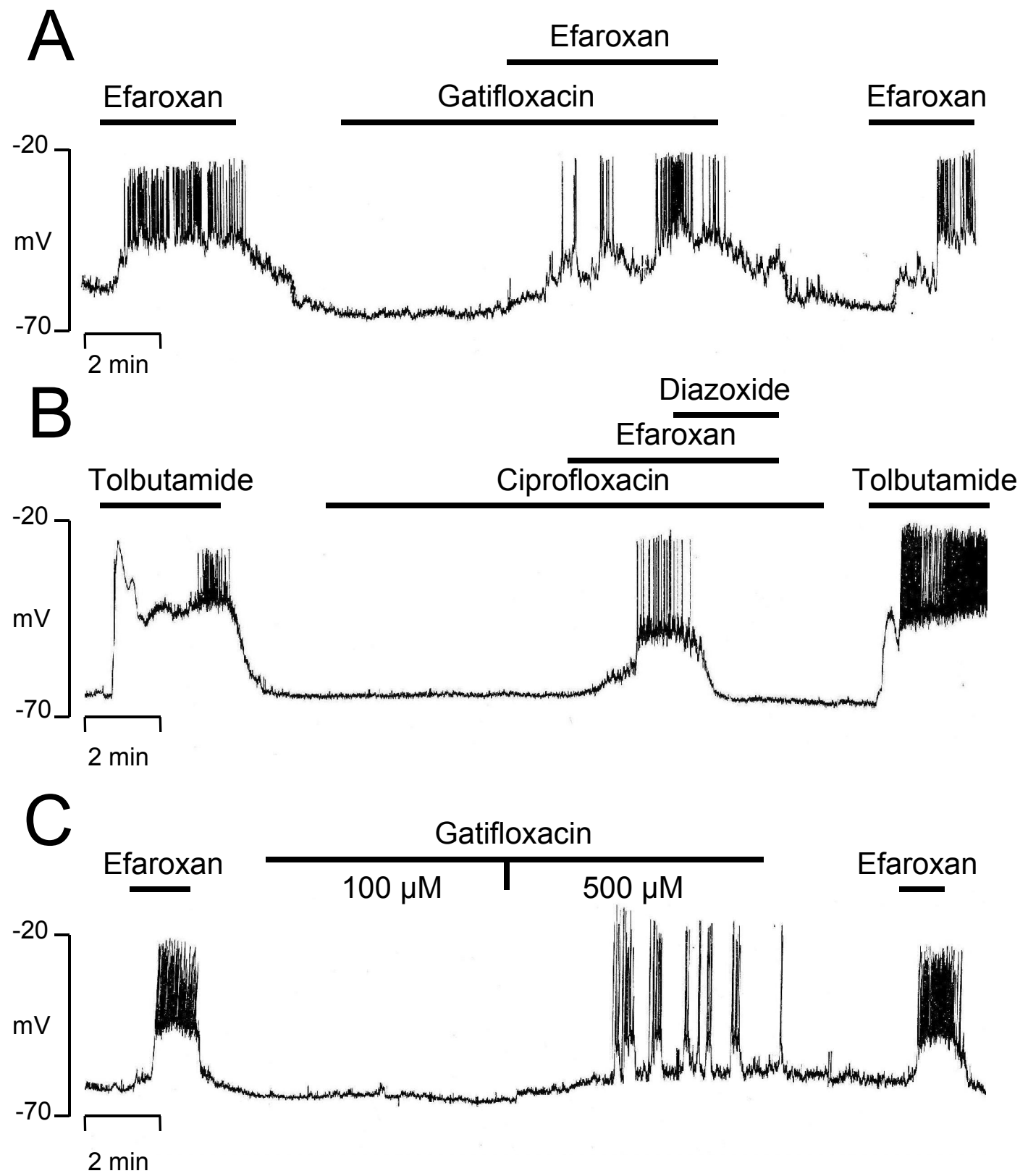

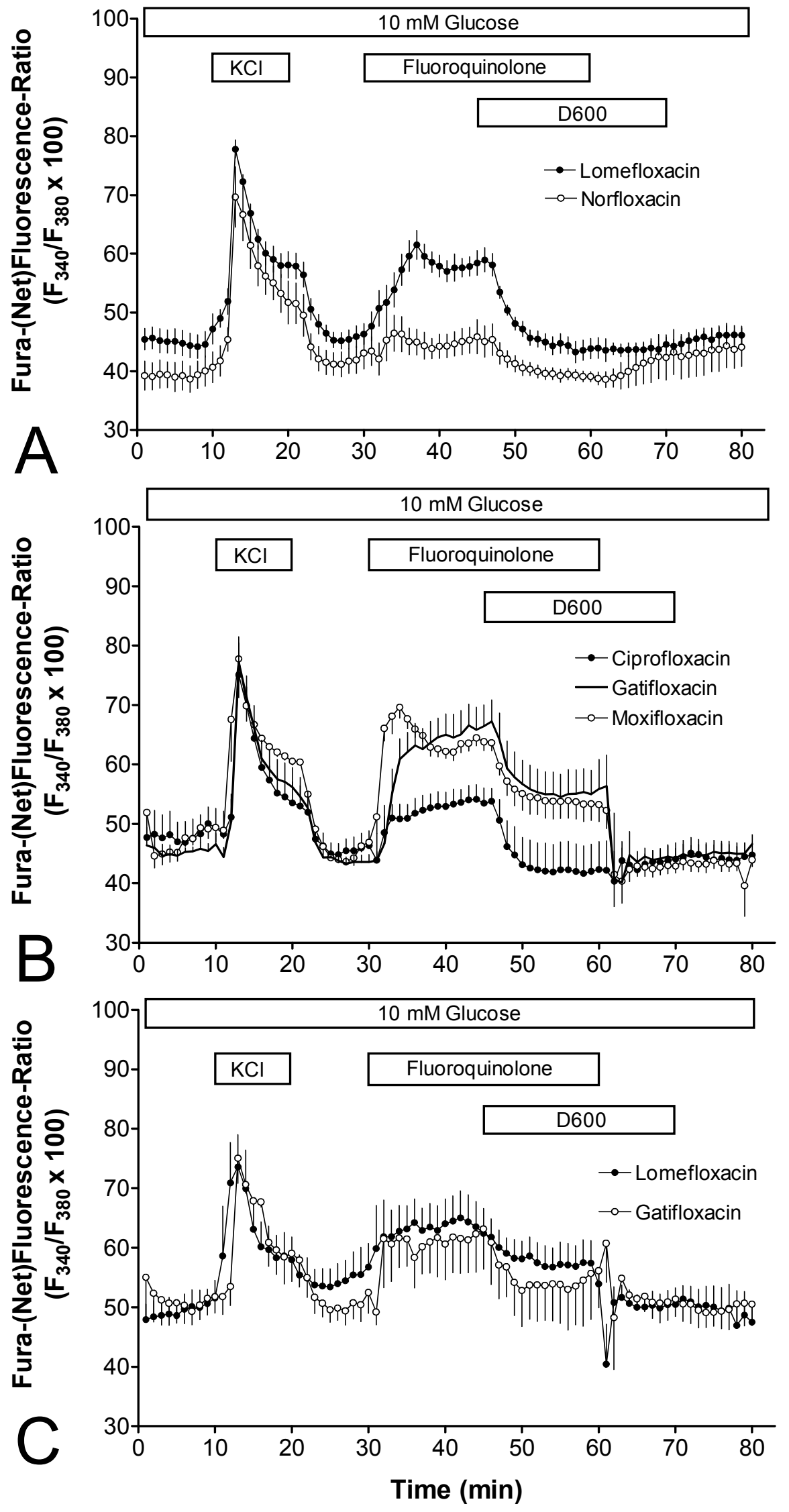

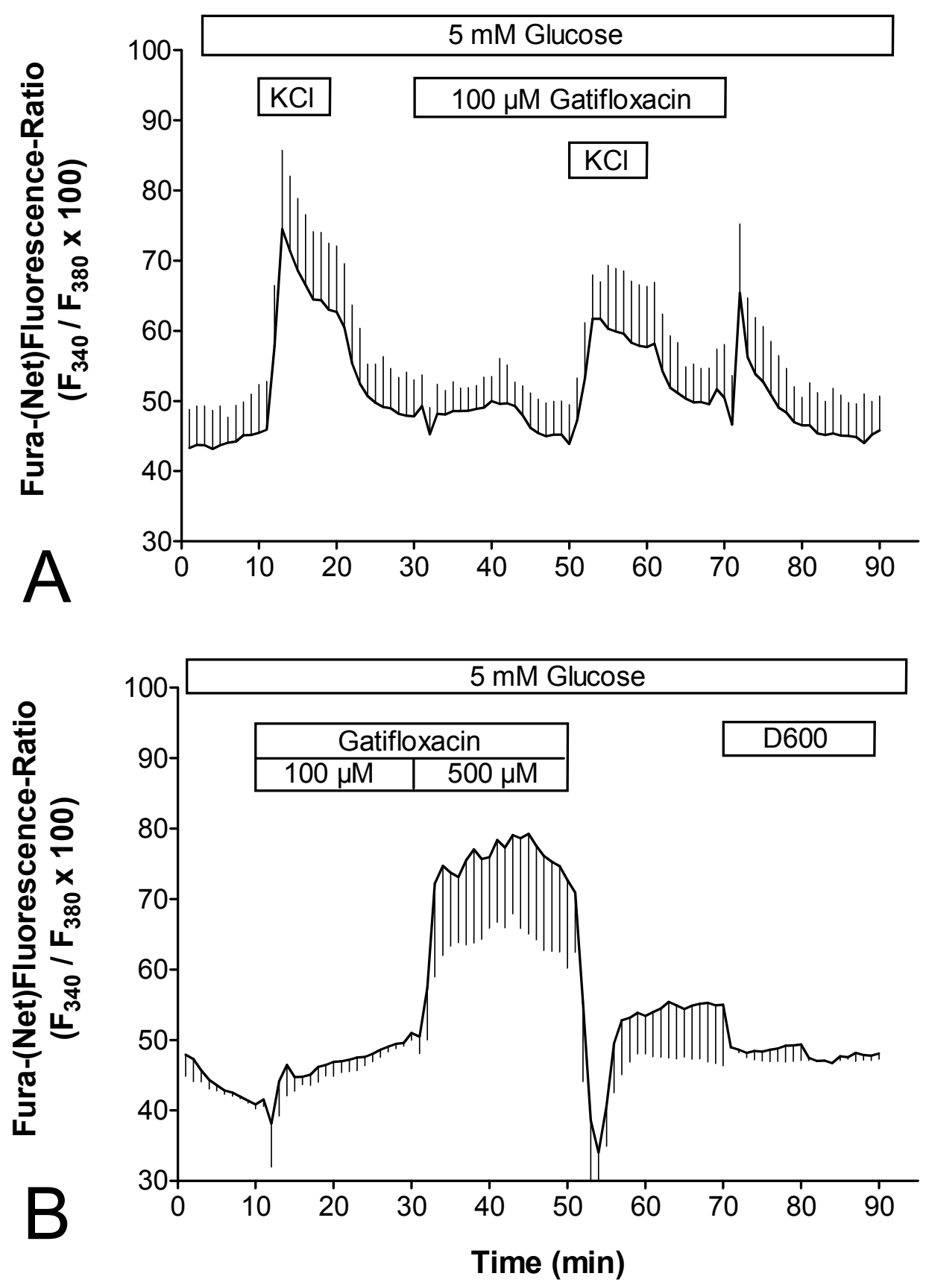